\title{
铁电体热释电系数的本征和场致增强模式的机理
}

陈勇 $^{1}$, 段文燕 ${ }^{1}$, 黎明锴 ${ }^{1,2}$, 曹万强 ${ }^{1,2 *}$, 潘瑞琨 ${ }^{1,2}$, 黄修林 ${ }^{1,2 *}$

1. 湖北大学物理与电子科学学院, 功能材料绿色制备与应用教育部重点实验室, 铁电压电材料与器件湖北省重点实验室, 有机化工新材料湖北 省协同创新中心, 武汉 430062;

2. 湖北大学材料科学与工程学院, 武汉 430062

* 联系人, E-mail: caowanq@163.com; huangxl@hubu.edu.cn

2020-02-01 收稿, 2020-03-05 修回, 2020-03-05 接受, 2020-03-06 网络版发表

国家自然科学基金(61874040)资助

摘要铁电材料制备的红外探测器主要有两种工作模式: 热释电体的无电场本征模式和铁电体的场致增强模式. 利用铁电体的唯象理论, 通过引入偶极子耦合, 得到了两种模式热释电系数的理论公式. 其数值模拟表明, 在热释 电体的本征模式中, 热释电系数随温度的上升而增加, 接近居里温度时急剧增大. 在铁电体的场致增强模式中, 热 释电系数由场致诱导极化的温度效应和偶极子的转动效应产生. 在低温区, 低电场时以偶极子的转动为主形成一 个尖锐的峰, 增大电场后变为以场致诱导极化为主. 温度升高, 以偶极子转动引起的热释电系数峰向高电场方向移 动, 在顺电相, 以场致诱导极化为主. 铁电体用于热释电效应时, 保持温度稳定性的基本方法是温度越高, 施加的电 场越大.

关键词铁电体, 热释电, 极化, 偶极子, 电场

铁电体在铁电相存在偶极子，随机等概率地分布 在各个可能的取向方向. 尽管温度变化会导致偶极子 的极化特性改变，但因对称分布使其宏观不表现出极 化强度的变化, 因而零电场时无热释电性. 众所周知, 当电场周期变化时，偶极子发生可逆的转动使极化强 度以电滞回线形式变化, 而极化强度的变化导致了各 种效应. 考虑电场增加的过程, 偶极子在电场方向的极 化强度和取向概率均增大, 导致宏观极化强度从零逐 渐向电场方向增大. 此时, 若铁电体的温度发生变化, 宏观极化强度也会发生相应的变化, 使铁电体具有电 场诱导的热释电效应. 若电场达到饱和之后撤消, 而偶 极子仍然保持排列状态不变, 该电场的作用过程称为 “压电极化”, 极化后的铁电体为热释电体. 因其具有零 电场时偶极子的定向排列, 温度和压力变化均会使平 行排列的偶极子产生宏观极化强度的变化, 引起表面
积累电荷的变化, 从而具有本征热释电性和压电性.

热释电体的本征热释电模式以具有强压电性的锆 钛酸铅 $(\mathrm{PZT})$ 和铌镁酸铅-锆钛酸铅(PMN-PZT)为主 ${ }^{[1,2]}$, 只能在居里温度 $\left(T_{\mathrm{c}}\right)$ 以下工作. 铁电体的场致增强模式 以钛酸锶钡(BST)和锆钛酸钡(BZT)为代表, $T_{\mathrm{c}}$ 接近室 温. 介电常数和热释电系数的峰值出现在 $T_{\mathrm{c}}$ 附近, 且峰 值和峰位会随偏置电场的大小发生移动 ${ }^{[3]}$. 揭示两种热 释电效应的物理机理并进行对比研究, 在理论和热释 电器件的开发应用方面均具有重要意义.

在传统的德文希耳的唯象理论中, 特征函数为弹 性吉布斯自由能. 但用于实验分析的铁电体理论研究 只考虑了极化强度沿电场方向的变化，没考虑偶极子 的转动效应，因而难以解释铁电体在施加外电场后产 生的各种效应. 将其扩展到三维, 增加反电场方向和垂 直于电场方向的弹性吉布斯自由能, 并由此导出施加

引用格式: 陈勇, 段文燕, 黎明锴, 等. 铁电体热释电系数的本征和场致增强模式的机理. 科学通报, 2020, 65: 2112-2119

Chen Y, Duan W Y, Li M K, et al. Mechanisms of pyroelectric coefficients in intrinsic mode and electric field enhancement mode for ferroelectrics (in Chinese). Chin Sci Bull, 2020, 65: 2112-2119, doi: 10.1360/TB-2020-0092 
外电场后平衡时的弹性吉布斯自由能和极化强度，才 是解释实验现象的可行方法.

尽管偶极子的耦合曾经被多次引入吉布斯自由能 中 $^{[4,5]}$, 但仅考虑了电场方向, 在物理意义上也没有与铁 电畴的现象产生关联, 故未解决与电滞回线相关的基 本问题. 本研究引人了偶极子的耦合效应: 当电场作用 于反向偶极子使其转动到正向, 产生了相邻平行排列 的偶极子, 它们会耦合形成更稳定的铁电畴. 运用此方

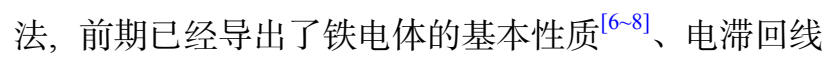
及储能效应 ${ }^{[9]}$ 、电卡效应 ${ }^{[10,11]}$ 、电致伸缩效应 ${ }^{[12]}$ 和介 电可调性 ${ }^{[13]}$. 另外, 还用此方法推导出了反铁电体的电 滞回线、介电常数和反铁电体储能与电场强度的关 系 ${ }^{[14,15]}$. 上述理论均能很好地解释实验结果. 在此基础 上，考虑电场对三维二级相变铁电体的作用和平行排 列偶极子的耦合效应, 分别推导了电场对极化强度和 偶极子转向对热释电效应的贡献，得到了热释电本征 模式和铁电场致增强模式的热释电系数与电场和温度 的关系, 用数值方法展示了模型效果, 并与实验结果进 行了对比.

\section{1 热释电唯象理论}

热释电效应(pyroelectric effect)是在一类材料中可 观察到的物理效应, 由于温度变化引起电荷释放 ${ }^{[16]}$, 用 热释电系数 $(p)$ 表示, 它是实验测量的极化强度 $(P)$ 对温 度 $(T)$ 的变化率:

$\Delta P=p \Delta T$.

唯象理论可以导出在电场 $(E)$ 作用下极化强度与温 度的关系, 因而可以导出铁电体的热释电系数. 外加电 场后偶极子的能量变化为矢量相乘的 $-\boldsymbol{E} \cdot \boldsymbol{P}$, 对二级相 变铁电体 $\left(T_{\mathrm{c}}=T_{0}\right)$ 吉布斯自由能 $(G)$ 的影响为

$G(P, E)=\frac{1}{2} \alpha_{0}\left(T-T_{0}\right) P^{2}+\frac{1}{4} \beta P^{4}-\boldsymbol{E} \cdot \boldsymbol{P}$,

其中, $T_{0}$ 为居里-外斯温度. 平行排列的偶极子会因电场 而产生耦合形成铁电畴以降低能量 ${ }^{[4]}$ :

$$
\begin{aligned}
G(P, E)= & \frac{1}{2} \alpha_{0}\left(T-T_{0}\right) P^{2}+\frac{1}{4} \beta P^{4} \\
& -J_{+} P^{2}-\boldsymbol{E} \cdot \boldsymbol{P}, \quad\left(J_{+}>0\right),
\end{aligned}
$$

其中, $J_{+}$为堣合系数. 在平衡条件下 $G$ 的一阶导数为零,
可由此求解式(2)和(3):

$\alpha_{0}\left(T-T_{0}\right) P_{0}(E)+\beta P_{0}{ }^{3}(E)-E=0$.

$P_{0}(E)$ 中，下标 0 表示在 $E$ 作用下的平衡值. 由式(4) 可求解出 $P_{0}(E)$. 当 $E=0$ 时, $P_{0}=0, P_{+}=\left(\alpha_{0}\left(T_{0}-T\right) / \beta\right)^{1 / 2}, P_{-}$ $=-P_{+}=-\left(\alpha_{0}\left(T_{0}-T\right) / \beta\right)^{1 / 2}$. “+”表示沿电场方向, “-”表示 与“+”反方向. $P_{+}$为自发极化强度 $P_{\mathrm{s}}, P_{0}=0$ 无实际意义. 当 $E>0$ 时, 需要设计程序求解. 铁电体中存在偶极子的 耦合 $J_{+}$时,

$\alpha_{0}\left(T-T_{0}\right) P_{++0}(E)+\beta P_{++0}^{3}(E)-2 J_{+} P_{++0}-E=0$.

$P_{++0}(E)$ 是平衡时沿电场方向的耦合极化强度, 即 铁电畴的极化强度. 热释电体的极化强度为 $P_{++0}(0)$, 可 由此导出:

$$
\begin{aligned}
& \alpha_{0}\left(T-T_{0}-2 J_{+} / \alpha_{0}\right)+\beta P_{++0}^{2}=0, \\
& p=\frac{\Delta P_{++0}}{\Delta T}=-\frac{\alpha_{0}^{1 / 2}}{2\left[\beta\left(T_{0}+2 J_{+} / \alpha_{0}-T\right)\right]^{1 / 2}}, \\
& T<T_{0}+2 J_{+} / \alpha_{0}, p=0, T \geq T_{0}+2 J_{+} / \alpha_{0} .
\end{aligned}
$$

式(6)的含义是高于居里温度的 $2 J_{+} / \alpha_{0}$ 为实际相变 的临界温度, 耦合系数 $J_{+}$反映了铁电性的强弱: 其值越 大, 畴的耦合强度越大, 畴越稳定, 且由畴所导致的介 电移峰效应越强, 电滞回线也越宽. 然而, 在高于临界 点的温度, 热释电系数为零.

在三维铁电体四方相的 6 个极化方向中，设它们分 别沿坐标轴的方向, 其中一个为电场方向, 另一个为反 电场方向, 其余 4 个垂直于电场方向. 式(2)中的 $P$ 与 $E$ 为 矢量乘积. 正向时 $G$ 的能量下降，反向时 $G$ 的能量上升, 垂直时不变. 然而, 反向极化强度对 $E$ 存在一个临界电 场 $E_{\mathrm{c}}$. 当电场 $E>E_{\mathrm{c}}$ 时, 反向偶极子 $G$ 的能谷消失, 其一阶 导数不存在, 意味着反向偶极子全部转到其他方向, 对 应着电滞回线的向上突变 ${ }^{[17]}$. 对 $G$ 的二阶导数为 0 , 可以 导出临界电场:

$$
E_{\mathrm{c}}=\frac{2 \alpha_{0}\left(T_{0}-T\right)\left(T_{0}-T\right)}{3}\left(\frac{\alpha_{0}\left(T_{0}-T\right)}{3 \beta}\right)^{1 / 2}, \quad T_{0} \geq T .
$$

随着电场正向增加, 各个方向的偶极子取向能级 由平衡时的 $G\left(P_{0}, E\right)$ 表示. 根据玻耳兹曼统计分布原 理, 可以导出为 ${ }^{[18]}$

$\rho_{+}=\frac{\exp \left(-G\left(P_{+0}, E\right) / k T\right)}{\exp \left(-G\left(P_{+0}, E\right) / k T\right)+4 \exp \left(-G\left(P_{0}\right) / k T\right)+\exp \left(-G\left(P_{-0}, E\right) / k T\right)}$, 


$$
\begin{aligned}
& \rho_{-}=\frac{\exp \left(-G\left(P_{-0}, E\right) / k T\right)}{\exp \left(-G\left(P_{+0}, E\right) / k T\right)+4 \exp \left(-G\left(P_{0}\right) / k T\right)+\exp \left(-G\left(P_{-0}, E\right) / k T\right)}, \\
& \rho_{0}=\frac{\exp \left(-G\left(P_{0}\right) / k T\right)}{\exp \left(-G\left(P_{+0}, E\right) / k T\right)+4 \exp \left(-G\left(P_{0}\right) / k T\right)+\exp \left(-G\left(P_{-0}, E\right) / k T\right)},
\end{aligned}
$$

其中, $\rho_{0}$ 是垂直于方向的极化强度取向概率, $\rho_{+}$和 $\rho_{-}$分 别是平行和反平行于 $E$ 方向的偶极子取向概率. 取向概 率的变化实质上为偶极子的转向. 在测量电滞回线的 实验中，有效部分是可测量的偶极子强度变化及其转 向对电荷的诱导. 垂直于电场方向的偶极子在测量中 为无效部分, 因此对电滞回线有影响的只有平行和反 平行于电场方向的偶极子. $E=0$ 时的极化强度为

$P_{\mathrm{t}}=\rho_{+} P_{+0}+\rho_{-} P_{-0}, P_{+0}>0, P_{-0}<0$,

其中, $P_{\mathrm{t}}$ 是两电极间测量的极化强度, 只有正和反电场 方向的偶极子有贡献，垂直于电场方向的偶极子没有 贡献. 由施加外电场后产生铁电畴时的平衡条件式(5) 可导出低于临界电场 $E_{\mathrm{c}}$ 时的极化强度:

$P_{\mathrm{t}}=\rho_{-}\left(P_{+0}+P_{-0}\right)+\left(\rho_{+}-\rho_{-}\right) P_{++0}, E<E_{\mathrm{c}}$,

和高于临界电场 $E_{\mathrm{c}}$ 时的极化强度:

$P_{\mathrm{t}}=\rho_{++} P_{++0}, E \geq E_{\mathrm{c}}$.

此时虽然没有了反向偶极子，但仍然存在垂直于电场 方向的偶极子, 它们不影响测量的极化强度, 但影响偶 极子的取向概率.

在温度高于居里温度的顺电相, 存在着离子间的位 移振动, 导致了介电常数. 无电场时 $G$ 的能谷在 $P=0$, 表 示无自发极化. 但加电场后会使 $G$ 的能谷移到 $P>0$, 在 $E$ 方向产生极化强度，即电场的诱导作用产生诱导极化， 同时在电场的反方向抑制离子的振动. 因偶极子的取 向概率仍然需要服从 $G$ 能谷之间的统计规律, 并非所有 离子的位移振动都会转变为诱导偶极子, 因而存在式 (13)的概率, $\rho_{++}$可由式 $(5)$ 根据 $E_{\mathrm{c}}=0, \rho_{-}=0$ 和 $G\left(P_{0}\right)=0$ 导出.

根据式(1)热释电系数的定义和加电场后极化强度 的表达式(12)和(13), 非夹持状态下的热释电系数可推 导得到:

$p=\frac{\Delta P_{\mathrm{t}}}{\Delta T}=\sum_{i} \frac{\Delta\left(\rho_{i} P_{i}\right)}{\Delta T}=\sum_{i}\left[\frac{\Delta P_{i}}{\Delta T} \rho_{i}+\frac{\Delta \rho_{i}}{\Delta T} P\right]$.

可以将式(14)分解出电场作用的两个部分: 转动的 贡献 $\left(p_{\mathrm{R}}\right)$ 和诱导极化强度 $\left(p_{\mathrm{P}}\right)$ 的贡献:

$$
\begin{aligned}
& p=p_{\mathrm{R}}+p_{\mathrm{P}}, \\
& p_{\mathrm{R}}=-\alpha_{0} \sum_{i} \rho_{i} P_{i} \varepsilon_{i}, \quad p_{\mathrm{P}}=-\sum_{i} \rho_{i} P_{i}\left[\sum_{j} \rho_{j} R_{j}-R\right],
\end{aligned}
$$

其中, $R_{i}=\frac{1}{k T^{2}}\left[G_{i}-T \frac{\partial G_{i}}{\partial T}\right]=\frac{1}{k T^{2}}\left[G_{i}-\frac{1}{2} \alpha_{0} T P_{i}^{2}\right]$.

低于临界电场时, 式(14)可以具体表示为

$$
\begin{aligned}
p= & -\alpha_{0}\left[\rho_{-}\left(P_{+0} \varepsilon_{+}+P_{-0} \varepsilon_{-}\right)+\left(\rho_{+}-\rho_{-}\right) P_{++0} \varepsilon_{++}\right] \\
& -\rho_{+} \rho_{-}\left[\left(2 P_{++0}-P_{+0}-P_{-0}\right)\left(R_{-}-R_{+}\right)\right],
\end{aligned}
$$

其中, $R_{+}=\frac{1}{k T^{2}}\left[G_{+}-\frac{1}{2} \alpha_{0} T P_{+0}^{2}\right], R_{-}=\frac{1}{k T^{2}}\left[G_{-}-\frac{1}{2} \alpha_{0} T P_{-0}^{2}\right]$, $\varepsilon_{+}=1 /\left[\alpha_{0}\left(T-T_{\mathrm{c}}\right)+3 \beta P_{+0}^{2}\right], \varepsilon_{-}=1 /\left[\alpha_{0}\left(T-T_{\mathrm{c}}\right)+3 \beta P_{-0}^{2}\right]$, $\varepsilon_{++}=1 /\left[\alpha_{0}\left(T-T_{\mathrm{c}}\right)+3 \beta P_{++0}^{2}-2 J_{+}\right]$.

高于临界电场时, 热释电系数为

$p=-\alpha_{0} \rho_{++} P_{++0} \varepsilon_{++}-\Delta \rho_{++} P_{++0}$,

其中,

$$
\Delta \rho_{++}=\rho_{++}\left(1-\rho_{++}\right) R_{++}, R_{++}=\frac{1}{k T^{2}}\left[G_{++}-\frac{1}{2} \alpha_{0} T P_{++0}^{2}\right] .
$$

在顺电相,

$P_{\mathrm{t}}=\rho_{+} P_{++0}, \rho_{+}=\frac{\exp \left(-G_{+} / k T\right)}{\exp \left(-G_{+} / k T\right)+4}$,

$p=\frac{\Delta P_{\mathrm{t}}}{\Delta T}=\frac{P_{++0}(T+\Delta T)-P_{++0}(T)}{\Delta T}$.

取温度差为合理的小值可求解式(18). 由理论所导 出的式(14) (18)构成了铁电体的热释电系数公式. 早 期的理论模型没有考虑偶极子的转动, 得到的低电场 热释电系数表达式近似为式(15)右边第一项, 其结论与 实验规律一致 ${ }^{[4]}$.

\section{2 结果与讨论}

上述理论公式从引人电场作用及偶极子在电场下 的耦合出发, 得到的式(11) (13)可用于计算电滞回线. 式(14) (16)包含的内容可用于计算与电滞回线对应的 介电常数. 式(4)可用于计算无电场时热释电体的热释 电系数. 式(14) (16)可用于计算铁电体在铁电相的电 场诱导热释电效应. 式(17) (18)可用于计算铁电体在 顺电相的电场诱导热释电效应. 将上述计算内容数值 化, 可以得到下述结论, 用于对比实验结果.

通过选用合适的热力学参数数值 ${ }^{[7 \sim 15]}$, 图 1 给出了 

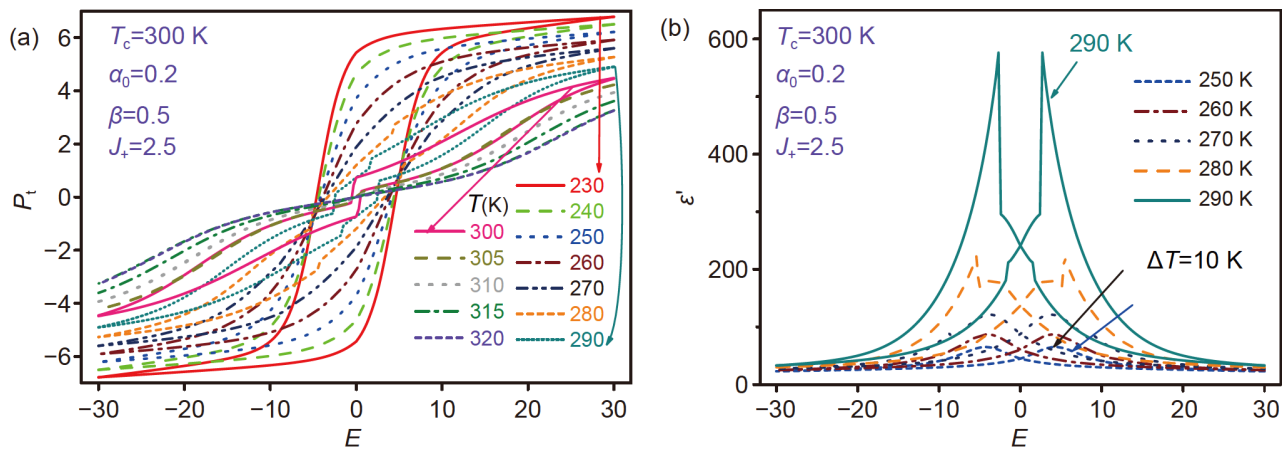

图 1 (网络版彩色)热释电效应所用铁电体的铁电性与介电性. (a) 电滞回线从铁电相 $(230 \sim 290 \mathrm{~K}$ )到顺电相(300 320 K)的变化规律; (b) 在铁电 相 $(250 \sim 290 \mathrm{~K})$ 偶极子耦合引起的介电常数双峰效应. 其中, 尖峰由临界电场效应引起 $\left(T_{\mathrm{c}}=300 \mathrm{~K}, \alpha_{0}=0.2, \beta=0.5, J_{+}=2.5\right)$

Figure 1 (Color online) Ferroelectric and dielectric properties of the ferroelectric used for analyzing the pyroelectric effect. (a) Changes of hysteresis loops from ferroelectric phase $(230-290 \mathrm{~K})$ to paraelectric phase $(300-320 \mathrm{~K})$; (b) double-peak effect of dielectric constant with electric field in ferroelectric phase $(250-290 \mathrm{~K})$ due to coupling of dipoles. The sharp peak effect represents the critical electric effect $\left(T_{\mathrm{c}}=300 \mathrm{~K}, \alpha_{0}=0.2, \beta=0.5, J_{+}=2.5\right)$

铁电体的铁电性与介电性. 图 $1(\mathrm{a})$ 展示了铁电体 $\left(T_{\mathrm{c}}=\right.$ $300 \mathrm{~K})$ 从低温铁电相 $(230 \mathrm{~K})$ 到高温顺电相 $(320 \mathrm{~K})$ 电滞 回线的变化规律. 在低温时因临界电场较大, 在达到临 界电场时大部分反向偶极子均已转向, 显示出的突变 效应较小。温度升高至接近 $T_{\mathrm{c}}$ 时, 临界电场效应较小, 反向偶极子转向显示的突变效应较大，导致电滞回线 和介电常数及其他物理量均会发生相应的突变. 因畴 的临界电场略大于偶极子, 因而在接近 $T_{\mathrm{c}}$ 时畴的反转 使电滞回线呈现出反铁电的形式. 当温度高于 $T_{\mathrm{c}}$ 时, 电 滞回线逐渐重合为单一回线. 理解电滞回线随温度的 变化规律是理解铁电体各种效应的基础.

图1(b)为与电滞回线对应的铁电相的介电常数. 尖 锐的介电峰表示临界电场时反向偶极子的转向效应. 低温时曲线的光滑介电峰对应电滞回线中极化强度的 最大变化点, 其电场值为回线的矫顽电场. 在顺电相电 滞回线重合为单一回线时, 介电常数表现为单峰.

热释电系数表现为与电滞回线对应的变化, 考虑 到实验与应用中均为单向增加电场的过程，因而铁电 体的场致诱导热释电系数仅考虑了从电场为 0 到最大 的回线初始增加过程. 正常铁电体和热释电体的热释 电系数为负值. 图 2 比较了在同样条件下的铁电体在各 种电场作用下的热释电系数和经超高电场极化成为热 释电体后在无电场时的热释电系数. 铁电体在低电场 时的负热释电系数在低温时会出现低谷，在反向偶极 子消失的临界温度出现了正的尖锐峰. 图 2 所示 $E>12$ 后 该尖锐峰逐渐减小并移向低温; $E=25$ 时热释电系数峰 在居里温度; $E>30$ 热释电系数峰移向较高温度且值较 小. 超高电场极化形成的热释电体具有简单热释电系

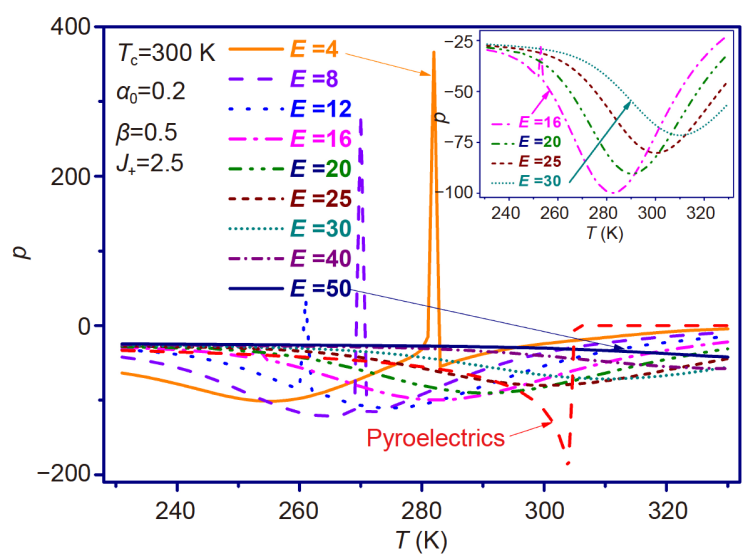

图 2 (网络版彩色) 铁电体在不同电场时热释电系数 $p$ 的温度谱和热 释电体在无电场时的热释电系数温度谱. 参量数值: $T_{\mathrm{c}}=300 \mathrm{~K}, \alpha_{0}=$ $0.2, \beta=0.5, J_{+}=2.5$

Figure 2 (Color online) Temperature spectra of pyroelectric coefficient $p$ of ferroelectrics on different applied electric fields, and temperature spectra of pyroelectric coefficient of pyroelectrics without applied electric field for the parameters: $T_{\mathrm{c}}=300 \mathrm{~K}, \alpha_{0}=0.2, \beta=0.5, J_{+}=2.5$

数变化规律：偶极子的塊合效应使其自身的 $T_{\mathrm{c}}$ 移向了 略高的温度, 热释电系数从低温到高温逐渐增大, 到 $T_{\mathrm{c}}$ 时达到极大. 高于 $T_{\mathrm{c}}$ 时热释电体转变为顺电相使热释 电系数为 0 . 因此, 尽管热释电体在 $T_{\mathrm{c}}$ 附近有较大的热 释电系数, 但低于 $T_{\mathrm{c}}$ 却远小于铁电体，且整体的温度稳 定性较差.

根据式(7), 铁电体在电场作用下的热释电系数 $p$ 由 场致偶极子转动导致的转动热释电系数 $p_{\mathrm{R}}$ 和电场诱导 极化的热释电系数 $p_{\mathrm{P}}$ 构成. 在不同温度下, 电场对其作 用的过程如图 3 所示. 在较低的温度下，热释电系数主 要由偶极子的转动贡献, $T=250 \mathrm{~K}$ 时热释电系数的峰在 

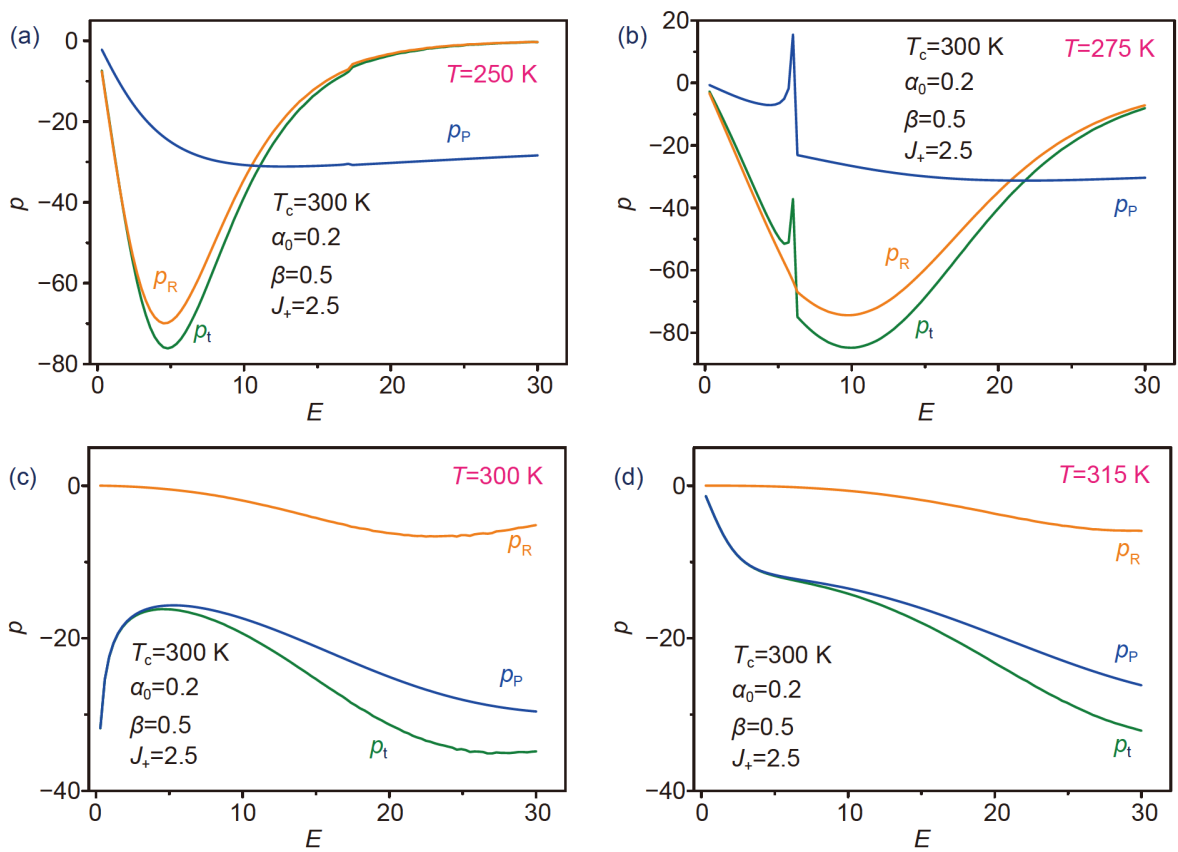

图 3 (网络版彩色) 不同温度下, 电场对热释电系数 $p$ 、转动热释电系数 $p_{\mathrm{R}}$ 和极化热释电系数 $p_{\mathrm{P}}$ 的影响. (a) $T=250 \mathrm{~K}$; (b) $T=275 \mathrm{~K}$; (c) $T=300 \mathrm{~K}$; (d) $T=315 \mathrm{~K}$

Figure 3 (Color online) Influences of electric field on pyroelectric coefficient $(p)$, rotational pyroelectric coefficient $\left(p_{\mathrm{R}}\right)$, and polarization pyroelectric coefficient $\left(p_{\mathrm{P}}\right)$ at different temperatures. (a) $T=250 \mathrm{~K}$; (b) $T=275 \mathrm{~K}$; (c) $T=300 \mathrm{~K}$; (d) $T=315 \mathrm{~K}$

较低的电场 $E=5$, 当温度升高到 $T=275 \mathrm{~K}$ 时, 热释电系数 峰减小且电场增大到 $E=10$, 主要贡献仍然是偶极子的 转动. 温度达到 $T_{\mathrm{c}}$ 时, 热释电系数的主要贡献变为了诱 导极化强度, 峰移到更高的电场 $E=30$ 且更平稳. 到了顺 电相, 主要贡献仍然是诱导极化强度, 且热释电系数不 断减小.

作为对比，图4给出了温度在 $150 \sim 450 \mathrm{~K}$ 范围内不 同电场强度对热释电系数 $p$ 、转动热释电系数 $p_{\mathrm{R}}$ 和电 场诱导极化的热释电系数 $p_{\mathrm{P}}$ 影响的效果. 在 $150 \sim 250 \mathrm{~K}$ 的温度范围内, 电场的作用以诱导极化强度的热释电
系数 $p_{\mathrm{P}}$ 为主, 对比图 $3(\mathrm{a})$, 诱导极化强度的热释电系数 $p_{\mathrm{P}}$ 在 $E=10 \sim 30$ 范围内平稳变化, 且为主要贡献; 而在 $E<10$ 的范围内 $p$ 却以转动热释电系数为主.

(111)取向的 $0.9 \mathrm{PMN}-0.1 \mathrm{PT}$ 铁电单晶外加电场后测 试其热释电系数, 随着电场的增大热释电系数的负能 谷向高温移动 ${ }^{[19]}$, 实验现象与图4(a)在280 320 K温度 区间的结果完全一致. 在掺杂的 $\mathrm{Na}_{0.5} \mathrm{Bi}_{0.5} \mathrm{TiO}_{3}$ 铁电陶瓷 中, 在 $50^{\circ} \mathrm{C}$ 加 $5 \mathrm{kV} / \mathrm{cm}$ 的电场时, 热释电系数的数值为 -0.5 ; 在 $100^{\circ} \mathrm{C}$ 加 $25 \mathrm{kV} / \mathrm{cm}$ 电场时, 热释电系数为 -0.125 , 且整个变化规律与本研究的结论完全一致: 在
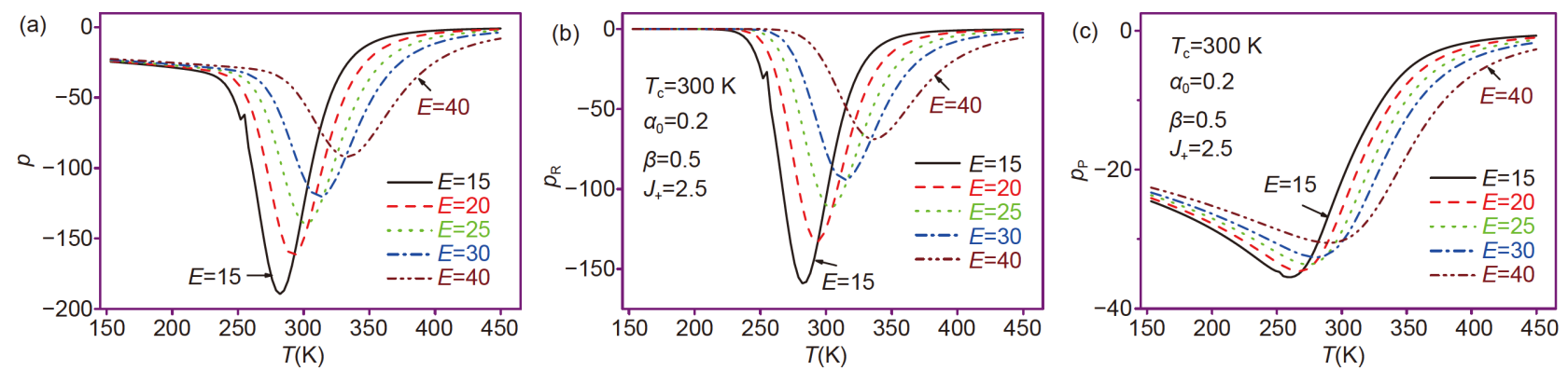

图 4 (网络版彩色) 在不同电场时 3 个热释电系数的温度谱. (a) 热释电系数 $p$; (b) 转动热释电系数 $p_{\mathrm{R}}$; (c) 极化热释电系数 $p_{\mathrm{P}}$

Figure 4 (Color online) Temperature spectra of the three kinds of pyroelectric coefficients at different electric fields. (a) Total pyroelectric coefficient $p$; (b) rotational pyroelectric coefficient $p_{\mathrm{R}}$; (c) polarization pyroelectric coefficient $p_{\mathrm{P}}$ 
低温下低电场时热释电系数有最低的能谷, 主要由转 动的偶极子贡献; 随温度升高偶极子的转动发生在较 宽的温度范围并需要较大的电场，导致了热释电系数 能谷的展宽. 对于其他的铁电材料 ${ }^{[20,21]}$, 热释电系数能 谷随 $T$ 和 $E$ 的变化均服从式(15)和(16)的结果.

具有热释电性和压电性的热释电体被实验证实其 热释电系数随温度变化较大, 使得热释电探测器工作性 能难以稳定 ${ }^{[1,2]}$. 本研究的理论工作给出相关的解释: 在 低于居里温度的温度范围内热释电系数较小, 远低于铁 电体在加电场后的情况, 而在居里温度附近会有急剧增 大的热释电系数, 且在顺电相突变为 0 . 此结论与三氟乙 酸二丁胺热释电体的实验结果完全相符 ${ }^{[22]}$.

最后需要指出的是, 对于一级相变铁电体, 只要在 $G$ 中加人 $P^{6}$ 项，可以得到与二级相变铁电体相同的 结果.

\section{3 结论}

本研究详细分析了热释电体产生热释电效应的物 理机理和铁电体场致增强效应的两种物理机理，并讨
论了电场对它们作用的温度谱, 得到如下结论:

(1) 热释电体在远低于居里温度时具有较小的热 释电系数; 接近居里温度的过程中热释电系数随温度 增加急剧增大, 表现为明显的温度不稳定性; 在高于居 里温度的顺电相热释电系数为 0 .

（2）铁电体的场致增强热释电效应存在两种因素: 极化强度效应和偶极子转动效应. 在低温区, 热释电系 数先在低电场以偶极子的转动为主形成一个尖锐的峰, 电场增大后变为以极化强度为主的较平稳的曲线. 温 度上升, 热释电系数峰向高电场方向移动, 同时峰的宽 度增大, 结论与实验结果一致. 另外, 温度越高, 热释电 系数峰所在电场值也越大.

（3）在顺电相, 场致诱导极化引起的热释电系数起 主要作用.

综上所述，铁电体的热释电系数在铁电相以偶极 子的转动为主, 为保证器件具有高热释电系数和良好 的温度稳定性，环境温度越高，需要施加的电场也越 大. 此原理不仅适用于铁电相温区，也适用于顺电相 温区.

\section{参考文献}

1 Clarke R, Glazer A M, Ainger F W, et al. Phase transitions in lead zirconate-titanate and their applications in thermal detectors. Ferroelectrics, 1976, 11: 359-364

2 Shaw C P, Gupta S, Stringfellow S B, et al. Pyroelectric properties of Mn-doped lead zirconate-lead titanate-lead magnesium niobate ceramics. J Eur Ceram Soc, 2002, 22: 2123-2132

3 Zhang G, Jiang S, Zeng Y, et al. High pyroelectric properties of porous $\mathrm{Ba}_{0.67} \mathrm{Sr}_{0.33} \mathrm{TiO}_{3}$ for uncooled infrared detectors. J Am Ceram Soc, 2009, 92 : $3132-3134$

4 Lines M E, Glass A M. Principles and Applications of Ferroelectrics and Related Materials. Oxford: Clarendon Press, 1997. 141-147

5 Zhong W L, Wang Y G, Zhang P L, et al. Phenomenological theory on ferroelectric surface effect and its relationship with transverse Ising model (in Chinese). Sci China Ser A Math, 1996, 26: 932-938 [钟维烈, 王玉国, 张沛霖, 等. 铁电体表面效应的唯象理论及其与横场Ising模型的关 系. 中国科学A辑: 数学, 1996, 26: 932-938]

6 Chen Y, Liu K H, Luo Q, et al. Correlation of dielectric dispersion with distributed Curie temperature in relaxor ferroelectrics. J Appl Phys, 2019, 125: 184104

7 Cao W Q, Liu P Z, Chen Y, et al. Effect of hysteresis of dipole on remnant polarization in ferroelectrics (in Chinese). Acta Phys Sin, 2016, 65: 137701 [曹万强, 刘培朝, 陈勇, 等. 铁电体中偶极子的滞后对剩余极化的影响. 物理学报, 2016, 65: 137701]

8 Chen Y, Bian M Y, Zhang C C, et al. Field induced effect of relaxor ferroelectrics at high electric field (in Chinese). Sci China Technol Sci, 2017, 47: 32-38 [陈勇, 市梦云, 张灿灿, 等. 高电场下弛豫铁电体的场致效应. 中国科学: 技术科学, 2017, 47: 32-38]

9 Cao W Q, Chen G L, Chen Y, et al. Polarization energy storage effect of ferroelectrics (in Chinese). Sci China Technol Sci, 2019, 49: 930-938 [曹 万强, 陈甘霖, 陈勇, 等. 铁电体的极化储能效应. 中国科学: 技术科学, 2019, 49: 930-938]

10 Qu S H, Mei M, Cao W Q, et al. Exothermic effect of entropy change in second-order phase transition ferroelectrics. Ferroelectr Lett Sect, 2018, 45: 66-75

11 Pan R K, Pan Y L, Chen Y, et al. Influence of ferroelectricity and dipole turning onelectrocaloric effect (in Chinese). Sci Sin-Phys Mech Astron, 2020, 50: 037701 [潘瑞琨, 潘一路, 陈勇, 等. 铁电性和偶极子转向对电卡效应的影响. 中国科学: 物理学 力学 天文学, 2020, 50: 037701]

12 Cao W Q, Fang F, Chen Y, et al. Effect of electric field induced strain for double-well ferroelectrics (in Chinese). Sci China Technol Sci, 2017, 47: 402-408 [曹万强, 方凡, 陈勇, 等. 双势阱铁电体的场致应变效应. 中国科学: 技术科学, 2017, 47: 402-408]

13 Pan R K, Li Y, Cao W Q, et al. Effects of electric field induced polarization on dielectric tunability and pyroelectric coefficient. Ferroelectr Lett 
Sect, 2017, 44: 81-92

14 Chen Y, Jiang C B, Qin L, et al. Polarization and dielectric effects of antiferroelectrics (in Chinese). Sci China Technol Sci, 2019, 49: 1309-1318 [陈勇, 姜朝斌, 秦路, 等. 反铁电体的极化与介电效应. 中国科学: 技术科学, 2019, 49: 1309-1318]

15 Cao W Q, Yue Y C, Chen Y, et al. Energy release effect in antiferroelectrics (in Chinese). Sci Sin-Phys Mech Astron, 2020, 50 : 067701 [曹万强, 乐耀昌, 陈勇, 等. 反铁电体的能量释放效应. 中国科学: 物理学 力学 天文学, 2020, 50: 067701]

16 Whatmore R W. Pyroelectric devices and materials. Rep Prog Phys, 1986, 49: 1335-1386

17 Qu S H, Zhao Q, Zheng K Y, et al. Theoretic research on recoverable energy release in antiferroelectrics. Ferroelectr Lett Sect, 2019, 46: 90-98

18 Qu S H, Cao W Q, Fang F, et al. Research on electrostrictive effect of second-order phase transition ferroelectrics. Ferroelectr Lett Sect, 2017, 44: 120-128

19 Luo L, Chen H, Zhu Y, et al. Pyroelectric and electrocaloric effect of <111>-oriented 0.9PMN-0.1PT single crystal. J Alloys Compd, 2011, 509: 8149-8152

20 Choi S W, Shrout R T R, Jang S J, et al. Dielectric and pyroelectric properties in the $\mathrm{Pb}\left(\mathrm{Mg}_{1 / 3} \mathrm{Nb}_{2 / 3}\right) \mathrm{O}_{3}-\mathrm{PbTiO}_{3}$ system. Ferroelectrics, 1989, 100: 29-38

21 Shen M, Li W, Li M Y, et al. High room-temperature pyroelectric property in lead-free BNT-BZT ferroelectric ceramics for thermal energy harvesting. J Eur Ceram Soc, 2019, 39: 1810-1818

22 Sun Z, Tang Y, Zhang S, et al. Ultrahigh pyroelectric figures of merit associated with distinct bistable dielectric phase transition in a new molecular compound: Di-n-butylaminium trifluoroacetate. Adv Mater, 2015, 27: 4795-4801 


\title{
Mechanisms of pyroelectric coefficients in intrinsic mode and electric field enhancement mode for ferroelectrics
}

\author{
Yong Chen ${ }^{1}$, Wenyan Duan ${ }^{1}$, Mingkai $\mathrm{Li}^{1,2}$, Wanqiang Cao ${ }^{1,2^{*}}$, Ruikun Pan $^{1,2}$ \& Xiulin Huang ${ }^{1,2^{*}}$ \\ ${ }^{1}$ Hubei Collaborative Innovation Center for Advanced Organic Chemical Materials, Key Laboratory of Ferro \& Piezoelectric Materials and Devices of \\ Hubei Province, Key Laboratory of Ministry of Education for the Green Preparation and Application of Functional Materials, School of Physics and \\ Electronic Science, Hubei University, Wuhan 430062, China; \\ ${ }^{2}$ School of Materials Science and Engineering, Hubei University, Wuhan 430062, China \\ * Corresponding authors, E-mail: caowanq@163.com; huangxl@hubu.edu.cn
}

A ferroelectric has a primary property of symmetry dipole distribution in its possible orientation directions. As pyroelectric coefficient of a ferroelectric is the derivative of the polarization with respect to temperature, caused by the change in temperature, a ferroelectric has not pyroelectric effect in absence of electric field, because when temperature changes, the change in polarizations due to the corresponding dipoles in each orientation direction is same. However, if the ferroelectric is polarized in strong electric field to cause irreversible domain, the polarized ferroelectrics or pyroelectrics has an intrinsic mode of pyroelectric effect. On the other hand, during a reversible polarization process by an externally applied electric field $(E)$, the ferroelectric will have electric field enhancement mode of pyroelectric effect due to two aspects: The rotation of dipoles towards $E$-direction, and the changes in polarizations of the $E$-direction and of its opposite direction. In this paper, the theoretical formulae of pyroelectric coefficient of the two modes are derived by introducing the dipole coupling on the basis of the Landau-Devonshire ferroelectric phenomenologic theory by considering two different responses of the two polarizations in these two opposite directions, along and anti- the $E$-direction. The two responses of the two opposite polarizations were described by two Gibbs free energies combined with the $E$. The orientation probabilities of dipoles in all possible orientation directions follows the Boltzmann statistic distribution. The changes in the orientation probabilities of dipoles can be considered as rotations of dipoles. With the increase in $E$, valley of the opposite Gibbs free energy rises. When the $E$ increases to a critical value, the valley of the Gibbs free energy disappears, accompanying by the re-distribution of dipoles, resulting in a sudden explosive increase of the rotation of the dipoles to the $E$-directions. This critical behavior in polarization causes various critical phenomena, such as polarization, dielectric constant, and pyroelectric coefficient. For the temperature far below the Curie temperature, the critical electric field is very large and critical behavior is rather small. By deducing the derivative of the orientation probabilities with respect to temperature, the contribution of the dipole rotation for the pyroelectric effect is derived. By deducing the derivative of the polarizations of the two opposite directions with respect to temperature, the contribution of the polarization for the pyroelectric effect is also derived. The numerical simulation for the intrinsic mode of the pyroelectrics shows that the pyroelectric coefficient increases with rising temperature, sharply in proximity to the Curie temperature. For the $E$-enhancement mode of ferroelectrics, the pyroelectric coefficient is ascribed to the temperature effects of the rotation effect of the dipole and of the $E$-induced polarization. In the low temperature region far from the Curie temperature, pyroelectric coefficient is produced mainly by the dipole rotation mode by exhibiting a peak in the low electric field, and then with the increase of the electric field, pyroelectric coefficient shows a flat variation due to the $E$-induced polarization. When temperature rises, the peak of the pyroelectric coefficient due to the dipole rotation moves towards high electric field direction. In paraelectric phase, the $E$-induced polarization dominates pyroelectric effect. For a constant electric field, the pyroelectric coefficient shows peak, which shifts to high temperature with the increase of the electric field. The basic method to maintain temperature stability for the high pyroelectric coefficient of ferroelectrics is to increase electric field if temperature rises.

ferroelectrics, pyroelectric, polarization, dipole, electric field

doi: 10.1360/TB-2020-0092 